\title{
EFFECT OF DIFFERENT DIETARY STARCH AND PROTEIN LEVELS ON PRODUCTIVE PERFORMANCE OF GROWING RABBITS
}

\author{
A.A. Hemid; F. Abdel-Azeem; M.A. Afifi and M.H. El-Sanhoury \\ Dept. Poultry Prod., Fac. Agric., Ain Shams University, Cairo, Egypt.
}

SUMMARY

$\mathrm{S}$ eventy two New Zealand White rabbits (NZW) at 25 days of age were used to study the effect of of different dietary starch and protein levels on productive performance, nutrients digestibility coefficients, carcass characteristics, digestive tract measurements, blood constituents, enzymes activity and economical evaluation. The rabbits were fed on six experimental diets containing 3 levels of starch $\{16$ (LS), 19 (MS) and 22\% (HS) $\}$ and 2 levels of protein $\{14$ (LP) and 16\% (OP) $\}$ in a factorial arrangement design. The results obtained are summarized as follows:

- Best results for live body weight (LBW) were obtained for rabbits fed $16 \%$ starch and $14 \%$ protein diet at the end of growth period (81 days of age). Decreasing of dietary starch and protein levels had a positive effect on average daily body weight gain (DBWG) in overall growth period (25-81 d.). Daily feed consumption (DFC) was affected by different levels of starch, but no protein level. Feed conversion ratio (FCR) was improved at moderate dietary starch and low dietary protein levels. Mortality rate of growing rabbits improved due to decreasing dietary protein levels. However, dietary starch levels had no effect.

- Rabbits fed low levels of starch and protein in their rations significantly increased DM, OM, CP, NFE, starch and sugar digestibility coefficients and nutritive values (TDN and DCP). Neither dietary starch nor protein levels had impact on CF, neutral detergent fiber (NDF), acid detergent fiber (ADF) and EE digestibility.

- There were not significant effects of starch and protein levels on dressing percentage, hot carcass weights $(\%)$, blood total protein, albumin, globulin, albumin/globulin ratio, liver activity enzymes (GOT and GPT). While, high starch level in the diet increased significantly liver weight (\%) regardless of protein content.

- Blood glucose, triglycerides and total protein content, amylase and protease enzymes activity in the stomach, ileum and cecum were significantly increased, while degree of $\mathrm{pH}$ for stomach, ileum and cecum contents was decreased by decreasing starch and protein levels in the diet. In addition, non-significant was observed in the cellulase and carboxymethylcellulase as affected by the different levels of protein and starch in all segents of the digestive tract. The results show that, total VFAs in the cecum and blood were high with $16 \%$ starch and $14 \%$ protein.

- Economic efficiency and performance index were improved for rabbits fed (MS-LP) diet. However, production efficiency factor was improved for rabbits fed (LS-LP) diet.

In growing rabbits, it was concluded that high correlation exists between dietary starch and protein levels which was reflected on productive performance, digestibility coefficients, digestive tract measurements and economic efficiency.

Keywords: Starch, protein, performance and growing rabbits.

\section{INTRODUCTION}

Low dietary amount of starch is recommended in the post weaning period in order to reduce digestive problems linked to the incomplete development of the enzymatic system in young rabbits (Maertens, 1992). This fact was also supported by the work of Xiccato et al. (2002), who concluded that, young rabbits were not able to digest starch completely. They added that, the starch source had no effect on growth performance, which was affected only by starch level. The same authors reported that, body weight gain and feed conversion were improved at higher level of starch compared to moderate levels, due to the increase in nutritive value and feed efficiency. However, if morbidity of young rabbits is taken into consideration, morbidity was numerically higher in rabbits fed high starch diets being (12.5\%) compared to rabbits fed low starch diets $(4.2 \%)$ but the difference was not significant.

The dietary protein (amino acids) requirements of weaned rabbits decrease with increasing age. The diets with a lower protein level, result in a significant reduced $\mathrm{N}$-excretion, this is of special importance to 
reduce the environmental pollution, in areas with a high density of animal production (Maertens, 1999). The low dietary protein level has less effect on reducing the protein content of the cecotropes than of the hard feces (Cheeke,1987), so that when dietary protein is low, the rabbit becomes increasingly efficient in conserving nitrogen, which indicates that the separation of protein into the cecotropes is more efficient at low protein levels. The growth rate of rabbits fed the protein $14.6 \%$ diet was close to that of rabbits fed the protein $16.5 \%$ diets and the feed conversion ratio was not significantly affected by the different protein diets (Berchiche et al., 1995). It seems that lowering starch and protein levels in the diet of growing rabbits decrease mortality rate which is a major problem facing rabbit's producer.

The enzyme activities are indicators of digestibility coefficient for good productive performance. They increase markedly with the age of the rabbit and due to the presence of micro-organisms that will determine the ability of the rabbit to utilize different levels of starch and protein. Amylase, protease, cellulase and carboxymethyl cellulase are some of activities provided by the intestinal microflora and digestive tract segments of the rabbit.

The present study aims at evaluating different levels of starch and protein in the diet of growing rabbits. Emphasis was also placed on productive performance, mortality rate, nutrients digestibility coefficients, carcass characteristics, digestive tract measurements, blood constituents, enzymes activity and economical evaluation.

\section{MATERIALS AND METHODS}

This study was carried out at the Centre of Agricultural Studies and Consultations (CASC), Rabbits Production Unit (RPU), Faculty of Agriculture, Ain Shams University, Cairo, Egypt.

Seventy two New Zealand White (NZW) rabbits at 25-81 days of age were used to examine the response of rabbits feeding on three different levels of dietary starch and two different level of crude protein in a factorial arrangement design. The rabbits were assigned randomly at six experimental treatments (12 rabbits / treatment). Each experimental group was divided into 4 replicates of 3 rabbits each.

The experimental diets were formulated to ensure an adequate supply of all nutrients recommended by NRC (1977) for growing rabbits. Treatments design was as follows: Low starch (16\%) and low protein (14\%) [LS-LP]; low starch (16\%) and optimum protein (16\%, as by NRC, 1977) [LS-OP]; moderate starch (19\%) and low protein (14\%) [MS-LP]; moderate starch (19\%) and optimum protein (16\%) [MSOP]; high starch (22\%) and low protein (14\%) [HS-LP] and high starch (22\%) and optimum protein (16\%) [HS-OP]. Composition of the diets is presented in Table (1). All diets were isocaloric and isofiberous and were provided in pelleted form.

Live body weight (LBW) of rabbits was recorded weekly in grams; the average daily weight gain (DWG) was individually calculated. Average daily feed consumption (DFC) was recorded weekly and feed conversion ratio (g feed /g gain) was calculated. Mortality rate was recorded weekly.

At the end of the experimental period, apparent nutrients digestibility were determined for experimental diets. Four animals from each experimental group were housed individually in metabolic cages that allowed feces and urine separation. The preliminary period was 7 days and collection extended to 6 days, feed intake was accurately determined. Feces excreted daily were collected in labeled polyethylene bags and samples were taken for the chemical analysis. Proximate analysis of the experimental diets and feces samples were carried out according to the A.O.A.C. (1990).

At the end of the growth trial, four randomly chosen rabbits (81 days of age) representing each group were slaughtered according to the standard technique of Cheeke et al., (1987). Blood samples were collected at slaughtering in heparinized glass tubes (4 samples per each treatment group). Blood plasma was separated by centrifugation at $3000 \mathrm{rpm}$ for 15 minutes. The collected plasma was stored at $-20^{\circ} \mathrm{C}$ until assay. Values of glucose, total protein, albumin, triglycerides and liver enzymes activity (GOT \& GPT) were estimated by using commercial Kits. The globulin values were obtained by subtracting the values of albumin from the corresponding values of total proteins. After blood samples were taken, the carcass traits were estimated. Dressing percentage included relative weights of carcass, giblets and head. Values of $\mathrm{pH}$ for stomach, ileum and cecum contents were measured immediately by using a digital $\mathrm{pH}$ meter.

The values were analyzed statistically using two-way analysis of variance method according to SAS (1998). Duncan's new Multiple Range procedure was followed to separate means (Duncan, 1955). The model applied was:

$$
\mathrm{Yijk}=\mu+\mathrm{Si}+\mathrm{Pj}+(\mathrm{SP}) \mathrm{ij}+\mathrm{Eijk}
$$


Where: $\mu=$ general mean. $\mathrm{Si}=$ dietary starch effect, $\mathrm{Pj}=$ dietary crude protein effect, $(\mathrm{SP}) \mathrm{ij}=$ starch by protein interaction effect and Eijk= experimental error.

Economic efficiency and performance index (PI) were calculated as follows:

Economic efficiency $=(\mathrm{A}-\mathrm{B} / \mathrm{B}) \mathrm{X} 100$

Where $A=$ price of $\mathrm{kg}$ gain in Egyptian pounds and $B=$ feed cost $/ \mathrm{kg}$ gain (LE).

The performance index (PI) was calculated according to (North, 1981) as follows: PI = (Live body weight $(\mathrm{kg}) /$ feed conversion) $\mathrm{X} 100$

The Production efficiency factor (PEF) was calculated according to (Emmert, 2000) as follows: PEF= \{Livability X mass (kg)/ FCR X Age in day\} X 100

Livability $=100$ - Mortality rate $(\%)$, Mass $(\mathrm{kg})=$ final live body weight $(\mathrm{kg})$.

Table (1). Composition of the experimental diets and their chemical analyses.

\begin{tabular}{|c|c|c|c|c|c|c|}
\hline \multirow[t]{2}{*}{ Ingredients } & \multicolumn{5}{|c|}{ Levels of starch and protein $(\%)$} & \multirow[b]{2}{*}{ HS-OF } \\
\hline & LS-LP & LS-OP & MS-LP & MS-OP & HS-LP & \\
\hline Yellow corn & 2.90 & 4.75 & 6.45 & 6.00 & 10.00 & 5.00 \\
\hline Barley & 11.0 & 11.5 & 16.5 & 20.6 & 22.0 & 29.7 \\
\hline Soy bean meal (44\%) & 3.60 & 7.35 & 2.45 & 4.00 & 1.30 & 0.70 \\
\hline Corn gluten meal (60\%) & 1.00 & 3.00 & 2.50 & 5.00 & 4.00 & 9.00 \\
\hline Wheat bran & 40.00 & 30.50 & 29.00 & 19.75 & 18.00 & 9.00 \\
\hline Clover hay & 35.10 & 37.50 & 38.05 & 40.25 & 41.00 & 43.10 \\
\hline Vegetable oil & 3.00 & 2.00 & 1.65 & 1.00 & 0.30 & 0.10 \\
\hline Bone meal & 1.00 & 1.00 & 1.00 & 1.00 & 1.00 & 1.00 \\
\hline Limestone & 1.50 & 1.50 & 1.50 & 1.50 & 1.50 & 1.50 \\
\hline Salt & 0.50 & 0.50 & 0.50 & 0.50 & 0.50 & 0.50 \\
\hline Rabbit premix* & 0.30 & 0.30 & 0.30 & 0.30 & 0.30 & 0.30 \\
\hline DL-methionine & 0.10 & 0.10 & 0.10 & 0.10 & 0.10 & 0.10 \\
\hline \multicolumn{7}{|c|}{ Chemical analysis (on as fed basis) } \\
\hline $\mathrm{DM}(\%)$ & 88.77 & 88.65 & 88.57 & 88.51 & 88.40 & 88.39 \\
\hline $\mathrm{CP}(\%)$ & 14.11 & 16.10 & 14.09 & 16.09 & 14.08 & 16.10 \\
\hline $\mathrm{CF}(\%)$ & 14.07 & 14.09 & 14.05 & 14.05 & 14.01 & 14.03 \\
\hline $\mathrm{EE}(\%)$ & 6.08 & 4.72 & 4.43 & 3.56 & 2.36 & 2.51 \\
\hline $\operatorname{NFE}(\%)$ & 45.88 & 44.97 & 47.41 & 46.28 & 48.96 & 47.47 \\
\hline $\operatorname{ASH}(\%)$ & 8.65 & 8.60 & 8.44 & 8.36 & 8.40 & 8.12 \\
\hline $\operatorname{Starch}(\%)$ & 16.15 & 16.08 & 19.03 & 19.13 & 22.00 & 22.01 \\
\hline Total Sugar (\%) & 6.05 & 5.99 & 6.38 & 6.31 & 6.70 & 6.59 \\
\hline $\operatorname{NDF}(\%)$ & 37.45 & 36.36 & 36.41 & 35.57 & 35.40 & 34.83 \\
\hline $\mathrm{ADF}(\%)$ & 20.58 & 20.98 & 20.94 & 21.35 & 21.30 & 21.77 \\
\hline \multicolumn{7}{|l|}{ B. Calculated Values } \\
\hline $\mathrm{DE}(\mathrm{K} \mathrm{cal} / \mathrm{Kg})$ & 2690 & 2698 & 2693 & 2715 & 2696 & 2735 \\
\hline Methionine (\%) & 0.36 & 0.35 & 0.40 & 0.41 & 0.39 & 0.45 \\
\hline Lysine (\%) & 0.89 & 0.86 & 0.85 & 0.84 & 0.83 & 0.87 \\
\hline Calcium (\%) & 1.46 & 1.49 & 1.49 & 1.51 & 1.51 & 1.54 \\
\hline Total phosphorous (\%) & 0.78 & 0.71 & 0.72 & 0.70 & 0.78 & 0.79 \\
\hline Methionine +Cystine (\%) & 0.61 & 0.62 & 0.63 & 0.66 & 0.65 & 0.65 \\
\hline
\end{tabular}

Rabbit premix *was obtained from Rovigypts Company Giza each $3 \mathrm{~kg}$ of rabbits premix contained:-

Vit.A 12000000 IU; Vit.D3 2000000IU; Vit.E 10000 mg; Vit.K3 2000 mg; Vit.B11000 mg; Vit.B2 5000 mg; Vit.B 6 $1500 \mathrm{mg}$; Vit.B12 $10 \mathrm{mg}$; Biotin $50 \mathrm{mg}$; Choline Chloride $250000 \mathrm{mg}$; Pantothenic acid $10000 \mathrm{mg}$; Nicotinic acid 30000 mg; Folic acid 1000 mg; Manganese 60000 mg; Zinc 50000 mg; Iron 30000 mg; Copper 10000 mg; Iodine $1000 \mathrm{mg}$; Selenium $100 \mathrm{mg}$; Cobalt $100 \mathrm{mg}$ and $\mathrm{CaCO}_{3}$ to $3000 \mathrm{mg}$. 


\section{RESULTS AND DISCUSSION}

\section{Growth performance of growing rabbits:}

Growth performance data of growing NZW rabbits as affected by different levels of starch and protein are presented in Table (2). Results indicated that, levels of starch and protein significantly $(\mathrm{P} \leq 0.01)$ affected live body weight (LBW) and daily body weight gain (DBWG) from 25-53, 53-81 and 25-81 days of age. Rabbits fed low levels of starch (16 or 19\%) during the first growth period (25-53d.) recorded significantly $(\mathrm{P} \leq 0.01)$ the higher LBW and DBWG. This decrease was irrespective of protein level and could be due to the effect of overloading carbohydrate. The high level of carbohydrate in rabbit diets would promote enteritis causing a proliferation of bacteria (Gidenne et al., 1998).

Rabbits fed diets containing low protein level significantly $(\mathrm{P} \leq 0.01)$ increased LBW and DBWG. This is probably due to the separation of protein into the cecotropes is more efficient at low protein levels. With low level of protein, cecotropes was recycled and the nitrogen retention increased (Cheeke, 1987).

The obtained results show that, during the first growth period, LBW and DBWG of the rabbits was highest with $16 \%$ starch and 14\% protein being (1353.29 and 29.79g). This agrees with the findings of Gidenne (2003) who reported that low level of dietary starch coupled with low level of dietary protein improved growth rate during growth period.

Concerning the second growth period (53-81d.), it was observed that, raising the dietary starch increased LBW and DBWG which could be due complete development of the enzymatic system as the rabbits grow up (Table 2). Accordingly the digestive system was able to digest carbohydrates highly. This leads to an increase in energy intake and the LBW increased accordingly. It seems that, rabbits' requirement of starch was high during the second growth period whereas, the low level of starch at $(16 \%)$ decreased DBWG. This fact was also supported by the work of Singh et al. (1997).

In the second growth period, the rabbits fed on $14 \%$ protein recorded the highest $(\mathrm{P} \leq 0.01) \mathrm{DBWG}$ compared to the level $16 \%$ protein. It's possible to reduce the protein supply during the second growth period (53-81d.) without any adverse affect on the growth performance (Maertens et al., 1997 and Maertens et al., 1998).

The results of this study show that, during the second growth period (53-81d.), DBWG of the rabbits was the highest with $22 \%$ starch and $14 \%$ protein being (27.57 g/day). Generally, the overall results show that, during the whole growth period, DBWG of the rabbits was highest with $16 \%$ starch and $14 \%$ protein being $(28.26 \mathrm{~g} / \mathrm{day})$.

Dietary level of protein had no significant effect on daily feed consumption (DFC) regardless of starch levels. These results agree with Berchiche et al. (1995), who found that, the average of DFC did not vary between different levels of protein.

Daily feed consumption was considerably higher in rabbits fed high levels of starch (19or 22\%) during the second growth period (53-81d.) than the same levels during the first growth period (25-53d.). It was observed that, as starch level of the ration increased from 16 to $19 \%$ DFC significantly decreased in the overall growth period (25-81d.) irrespective of protein content. Parigi Bini et al. (1990) and Nizza and Moniello (2000) reported that, the high level of starch in the diet decreased DFC. The opposite trend was recorded when starch was increased from 19 to $22 \%$ starch level. Concerning overall growth period (25$81 \mathrm{~d}$.), it is obvious that, DFC of the rabbits was low with $19 \%$ starch and $14 \%$ protein being (74.62g/day).

The effects of different levels of starch and protein on feed conversion ratio (FCR) are shown in Table (2). The best FCR was recorded significantly $(\mathrm{P} \leq 0.01)$ for rabbits fed moderate level of starch $(19 \%)$ compared with the low and high levels in all growth periods of the experiment. Similar results were obtained by Xiccato et al. (2002) who found that, 20.6\% level of starch improved FCR than 17\% starch level. Starch digestion in young rabbit's exhibits pronounced differences compared with adults, attributable to the relative importance of intestinal digestion and caecal fermentation on overall fecal digestibility (Blas and Gidenne, 1998).

Lowering protein level from 16 to $14 \%$ improved feed conversion ratio at all experimental periods irrespective of the different starch levels. This agrees with the findings of Maertens et al. (1997), who reported that, the improvement of FCR was associated with the decreasing of protein level. This result may be due to high protein: energy ratio which caused negative effect on FCR as reported by Kjaer and Jensen, (1997). On the other hand, the results disagree with the findings of Berchiche et al. (1995) who found that, protein level had no effect on FCR.

From the overall results, it can be concluded that $19 \%$ starch and $14 \%$ protein gave the best feed conversion ratio (2.74 $\mathrm{g}$ feed/g gains). 
Data in Table (2), showed that, dietary protein level significantly affected the survival rate. Lowering the protein level in the diets from 16 to $14 \%$ decreased the mortality rate $(22.22 \mathrm{Vs} 11.11 \%)$ irrespective of starch content. This result may be due to the effect of low protein on preventing the enteric diseases (De Blas et al., 1981 \& Kjaer and Jensen, 1997). Starch levels had no significant effect on survival rate. This result agrees with the findings of Xiccato et al. (2002), who reported that, morbidity rate was not affected by increasing the level of starch from 17.0 to $20.6 \%$.

The interaction between different levels of protein and starch (Table 2) showed highly significant effects on LBW, DBWG, DFC and FCR. These parameters increased significantly $(\mathrm{p} \leq 0.01)$ for growing NZW rabbits fed diet containing $14 \%$ protein and $19 \%$ level of starch.

\section{Nutrients digestibility coefficients:}

The results of apparent digestibility and nutritive values for the experimental diets are presented in Table (3). Rabbits fed lowering starch and protein levels in the rations significantly increased DM, OM, CP, NFE, Starch and Sugar digestibility coefficients and nutritive values (TDN and DCP). The same results were observed by Frage et al. (1983); De Blas et al. (1995) and Aderibighe et al. (1992).

The reduction in digestion coefficients associated with high level of starch may be due to overload carbohydrates (Cheeke et al. 1986) and consequently, increasing bacteria activity which caused enterotoxaemia (Lebas and Maitre, 1989; Peeters et al., 1993; Blas et al., 1994 and Maertens, 1995. The effect of high protein level on the reduction of digestion coefficients could be explained by the proliferation of neonatal bacteria (De Blas et al., 1981, Frage et al., 1983 and Kjaer and Jensen 1997). The reduction of TDN \% in groups fed high level of starch and protein was due to the decreasing digestibility coefficients of $\mathrm{CP}$ and NFE in these groups. The results indicated that, there was no significant effect of starch and protein levels on EE, CF, NDF and ADF digestibility coefficients. This agrees with the findings of El-Sanhoury (2000), who found that, there was no effect of starch level on CF digestibility. Sarhan (2001) reported that, digestion coefficients of all nutrients and nutritive values except Digestible crude protein (DCP) were not affected by dietary protein levels. Similar result was obtained by Cheeke et al. (1986).

\section{Carcass characteristics:}

Results concerning the effect of different levels of starch and protein on carcass traits are presented in Table (4). There were not significant effects $(\mathrm{p}>0.05)$ of starch and protein levels on dressing percentage and hot carcass weights (\%). This agrees with the findings of Ouhayoun (1998) and Nizza and Moniello (2000) who found that carcass was weakly affected by dietary starch level. These results are in agreement with Maertens et al. (1997), who found that dressing percentage did not vary at any protein level. Xiccato et al. (1993) reported that, diet with different digestible protein/digestible energy ratio given during the fattening period did not modify carcass.

The dietary starch level affected liver weight (\%). It is obvious that high starch level in the diet increased significantly liver regardless of protein content. This may be due to conversion large quantities of carbohydrates to fat with liver. This fact was also supported by the work of Thomas et al. (1984).

Data concerning digestive tract parts (\%) were recorded for each experimental rabbit and measurements are listed in Table (4). The dietary starch and protein levels did not affect weights of empty stomach, full cecum and empty cecum. However, results presented in Table (4) showed that most digestive tract measurements increased with increasing the dietary starch and protein levels. Abdel-Azeem et al. (2000) reported that, the high level of starch in the diet increased stomach contents, empty small intestine, small intestine contents, cecum length, empty large intestine and large intestine contents, but not empty stomach. El-Sanhoury (2000) found that, increasing the dietary starch level increased the weight of full or empty large small intestine. This may be explained on the basis that starch increased the activity of flora in large intestine, which may be increased bacterial count and gasses, so the size of large intestine was increased. Also, increasing the dietary starch level increased appendix length due to the storage of starch, protein and actions of bacteria.

\section{Blood constituents:}

Mean values of blood constituents presented in Table (5). The highest values of glucose and triglycerides were recorded for rabbits given the diets containing either low starch level or low protein level while; the lowest values were achieved by rabbits given high starch diets or high protein diets. Results of glucose and triglyceride contents were within the normal levels (Fox et al., 1984 and Chiericato et al., 1985). Gascon and Verde (1985) who found that, glucose decreased significantly $(\mathrm{P} \leq 0.01)$ when compared to healthy rabbits. This result may be due to the effect of low protein on preventing the enteric diseases (De Blas et al., 1981 \& Kjaer and Jensen, 1997). 
No significant effects $(\mathrm{P}>0.05)$ were detected in values of the total protein, albumin, globulin, albumin/globulin ratios, liver activity enzymes (GOT and GPT) due to feeding diets containing different levels of starch and protein. These results are in harmony with Abdel- Azeem et al. (2000). However, values of total plasma protein and its fractions are within the normal ranges reported by Melby and Altman (1974). They found that the normal values of total protein in rabbits ranged between 4.9 and 7.2 $\mathrm{g} / 100 \mathrm{ml}$ and the normal values of blood albumin ranged between 3.3 and $5.1 \mathrm{~g} / 100 \mathrm{ml}$, while the normal values of globulin between 1.85 and $3.6 \mathrm{~g} / 100 \mathrm{ml}$.

\section{Protein contents, total volatile fatty acids, $\mathrm{pH}$ and digestive enzyme activities of growing rabbits:}

Data presented in Table (6) clearly show that total protein content in the stomach, ileum and cecum was significantly increased by decreasing starch and protein levels in the diet. Stomach was noticed to be contained the lowest mean level of total protein as affected by dietary starch and protein levels. These results were confirmed by the finding of Jankiewicz et al. (1997), who reported that degradation of many proteins was observed under gastric conditions, the protein degradation was clearly enhanced after $45 \mathrm{~min}$ of pancreatic digestion. This explained why total protein content was low in the content of the stomach.

It will be noticed that, as starch content of the ration increased from 16 to $22 \%$ total VFA significantly decreased at the end of the experiment. This decrease was regardless of protein level and could be due to the effect of overloading carbohydrate. The high level of starch in the rabbit diets from 10 to $30 \% \mathrm{DM}$ decreased total VFA (Gidenne et al., 2000). Low protein level in the diet significantly increased total VFA regardless of starch content. The results of this study show that, total VFA in the cecum and blood were high with $16 \%$ starch and $14 \%$ protein being 3.81 and $3.01 \%$.

Data listed in Table (6) show that the $\mathrm{pH}$ of stomach and ileum contents were as usual acidic and near neutral, respectively, while cecal $\mathrm{pH}$ was slightly acidic. It was noticed that the main $\mathrm{pH}$ of stomach, ileum and cecum was influenced by fed on different levels of starch and protein. Dietary starch level weakly affected cecal fermentation, with a slight reduction of cecal $\mathrm{pH}$ in rabbits fed high starch diets, as described by Bellier and Gidenne (1996), and without effects on ammonia, total VFA and VFA proportions. However, Xiccato et al. (2002) reported that cecal pH tended to be slightly higher in rabbits fed moderate starch diets neither total VFA production nor VFA proportion were affected. In contrast to the present study, Deshmuk et al., (1997) found that there was no significant difference in pH and VFA concentration in rabbits fed isoenergetic diets containing 13,16 or $20 \%$ protein.

Amylase and protease enzymes activity was found in the stomach, ileum and cecum of the rabbits was increased with decreasing starch and protein levels in the diet. In addition, non significant was observed in the cellulase and carboxymethyl cellulase as affected by the different levels of protein and starch in all segments of the digestive tract. Concerning digestion enzymes were noticed to be markedly higher at $16 \%$ starch and 14\% protein in all segments of the digestive tract (Table 7). Deshmuk et al. (1997) found that carboxymethyl cellulase (CMCase) was absent in the contents of stomach and small intestine of rabbit fed on isocaloric diets containing 13,16 and $20 \%$ protein, which in contrast to the present finding. The authors also, reported that the level of protein in the diets does not affect activities of protease and xylanase enzymes, except cecal CMCase activity that was highest in the rabbits fed high protein diet.

\section{Economic and productive efficiency of growing rabbits:}

Table (8) represents economic efficiency, performance index (PI) and production efficiency factor (PEF) of the growing rabbits fed different levels of starch and protein. It will be noted that best economic efficiency, PI and PEF was obtained for rabbits fed (19\%) dietary starch level irrespective of protein content. The performance index increase may by relate to the improvement in live body weight and feed conversion ratio. Regardless of starch level, economic efficiency, PI and PEF of rabbits were affected by dietary protein content. It is obvious that, low protein level in the diet increased these parameters. The results of this study show that, economic efficiency and PI of the rabbits were highest with 19\% starch and $14 \%$ protein being (311.80 and $74.54 \%$ ) respectively. While, PEF of the rabbits was improved with $16 \%$ starch and $14 \%$ protein being $(79.92 \%)$ due PEF equation concluded the livability.

\section{REFERENCES}

A.O.A.C. (1990). Official Methods of Analysis, Association of Official Analytical Chemists. 15th edition, Washington, USA.

Abdel-Azeem, F.; Y.M. El-Hommosany and G.M. Nematallah Ali, (2000). Effect of Citric acid in diets with different starch and fiber levels on productive performance and some physiological traits of growing rabbits. Egyptian Journal of Rabbit Science, 10 (1):121-145. 
Aderibighe, A.O.; Y. Tor-Aghidye; P.R. Cheeke and N.M. Patton (1992). Interactions of fermentable carbohydrate and protein on nutrient digestibility, performance and enteritis in weaning rabbits. J. Appl. Rabbit Res., 15:1225-1234.

Bellier, R. and T. Gidenne (1996). Consequences of reduced fiber intake on digestion, rate of passage and cecal microbial activity in the young rabbit. Brit. J. Nutr., 75:353-363.

Berchiche, M.; F. Lebas and J.Ouhayoun (1995). Utilization of field beans by growing rabbits: 1-Effect of supplementations aimed at improving the sulfur amino acid supply. World Rabbit Sci., 3 (1):35-40.

Blas, E.; C. Cervera and J. Fernandez-Carmona (1994). Effect of two diets with varied starch and fiber levels on the performances of 4-7 week old rabbits. World Rabbit Sci., 2:117-121.

Blas, E. and T. Gidenne (1998). Digestion of starch and sugars. In: DeBlas C. and Wiseman J. (ed). The Nutrition of the Rabbit. CABI Publishing. CAB International, Wallingford Oxon, UK, 17-38.

Cheeke, P.R (1987). Rabbit feeding and nutrition. A Cadeic Press, New York.

Cheeke, P.R.; M.A. Grobner and N.M. Patton (1986). Fiber digestion and utilization in rabbits. J. Appl. Rabbit Res., 9(1):25-30.

Cheeke, P.R.; N.M. Patton; S.D. Lukefahr and J.I. McNitt (1987). In: Rabbit

Chiericato, G.M.; M.P. Schiapelli and U. Filotto (1985). Studo della relazioni esistenti fra prestazioni produttive eprobilo metabolico nel coniglio. Estratto da Coniglicoltura XXLL, N. 12.

DeBlas, J.C.; E. Perez and M.J.F. Galvez (1981). Effect of diet on feed intake and growth of rabbits from weaning to slaughter at different ages and weights. J. Anim. Sci., 52:1225-1232.

DeBlas, J.C.; E. Taloada; G.G. Mateos; Nuria Nicodemus and J. Mendez (1995). Effect of substitution of starch for fiber and fat in isoenergetic diets on nutrient digestibility and reproductive performance of rabbits. J. Anim. Sci., 73:1131-1137.

Deshmuk, S.V.; D.N. Kamra and N.N. Pathak (1997). Effect of dietary protein level on some biochemical constituents and hydrolytic enzyme activities in gut contents of New Zealand White rabbits. International J. of Anim. Sci., 12 (1):1-3.

Duncan, D.B. (1955). Multiple range and Multiple F tests. Biometrics, 11:1-42.

El-Sanhoury M.H. (2000). Effect of some nutrition factors on early weaning of rabbits under Egyptian conditions. Thesis M.Sc., Fac. Agr., Ain Shams Unvi., Egypt.

Emmert, J. (2000). Efficiency of phase-feeding in broilers. Proceeding, California Animal Nutrition Conference. May 10-11. Fresno California, USA.

Favarato, M. and P. Zatta (1990). Chemico-Clinical characterization of rabbit serum. J. Appl. Rabbit. Res., 13:14-15.

Fox, J.G.; B.J. Cohen and F.M. Loew (1984). Laboratory Anim. Medicine Chpt, 8:207-240

Frage, M.J.; J.C. DeBlas; E. Perez; J.M. Rodriguez; C.J. Perez and J.F. Galvez (1983). Effect of diet on chemical composition of rabbits slaughtered at fixed body weight. J. Anim. Sci., 56:1097-1104.

Gascon, M. and J. Verde (1985). Study of biochemical profiles in diarrhea rabbits. J. Appl. Rabbit. Res., 8:141-143.

Gidenne, T.; O. Madec and P. Arveux (1998). Effects de la nature de la lignocellulose sur la digestion et les performances zootechniques du lapin en croissance. In: Proc. 7 emes Journ. Resh. Cunicole Fr., Lyon. ed. INRA- IRTAVI: 151-154. Abstract.

Gidenne, T. (2003). Fibers in rabbit feeding for digestive troubles prevention: respective role of lowdigested and digestible fiber. Livestock Prod. Sci., 81:105-117.

Gidenne, T.; V. Pinheiro; E. Falco and L. Cunhal (2000). A comprehensive approach of the rabbit digestion consequence of a reduction of dietary fiber supply. Livest. Prod. Sci., 64:225-237.

Jankiewcz, A.; W. Baltes and K.W. Bogl (1997). In vitro study of the gastrointestinal stability of celery allergens. Food and Agricultural immunology, 9(3):203-217.

Kjaer, J.B. and J.A. Jensen (1997). Peritoneal fat, carcass conformation, gain and feed efficiency of growing rabbits as affected by dietary protein and energy content, 5(3):93-97.

Lebas F. and I. Maitre (1989). Alimentation de presevrage. Etude d'un aliment riche en energetic et pauvre en proteins, Resultats de 2 essais. Cuniculture, 16:135-140. Abstract.

Maertens, L. (1992). Rabbits nutrition and feeding. A review of some recent developments. J. Appl. Rabbit Res., 15:889-913.

Maertens, L. (1995). Effect of dietary technological treatments on the performances of rabbits before and after weaning. Proc. 7th Hungarion Rabbit Production day, Kaposvar 24 May, 1-11.

Maertens, L. (1999). Towards reduced feeding costs, dietary safety and minimal mineral excretion in rabbits. (A review) World Rabbit Sci., 7 (2):65-74.

Maertens, L.; C. Cavani; F. Luzi and F. Capozzi (1998). Influence du rapport proviennes/énergie et de la source énergétique de l'aliment sur les performances, l'excrétion azote et les caractéristiques de la 
viande des lapins en finition. In: proceeding of the 7eme Journ Res. Cunicole, Fr., 9-10 Juin, Lyon, France, ITAVI publ. Paris, 163-166.

Maertens, L.; F. Luzi and G. DeGroote (1997). Effect of dietary protein and amino acids on the performance, carcass composition and N-excretion of growing rabbits. Ann. Zootech., 46:255-268.

Maheswari, D.K.; H. Johan; J. Paul and A. Varma (1993). Wheat straw potential substrate for cellulase production using trichoderma reesei. World J. of Microbiology and Biotechnology, 9:1(5):120-121.

NRC (1977). National Research Council. Nutrient requirements of rabbits. National Academy of Science, Washington, D.C

Nizza A. and G. Moniello (2000). Meat quality and caecal content characteristics of rabbit according to dietary content and botanical origin of starch. World Rabbit Sci., 8:3-9.

North, M.O. (1981). Commercial chicken. Production Annual. 2nd edition, Av., publishing company I.N.C., Westpost. Connecticut, USA.

Ouhayoun, J. (1998). Influence of the diet on rabbit meat quality. In: De Blas C., Wiseman J., (ed). The nutiration of the rabbit, CABI Publishing. CAB International, Wallingford Oxon, uk, 177-195.

Parigi Bini, R.; G. Xiccato; M. Cinetto and A. Dalle Zotte (1990). Influenza del contenuto di amido alimentare sulla produttivita, sulla digeribilitae sulla composizione corporea di conigli in accrescimento. Zoot. Nutr. Anim., 16:271-282. Abstract.

Peeters, J.E.; R. Orsenigo; L. Maertens; D. Galazzi and M. Colin (1993). Influence of two iso-energetic diets (starch Vs fat) on experimental colibacillosis (EPEC) and iota-enterotoxaemia in early weaned rabbits. World Rabbit Sci., 1:53-66.

Sarhan, M.A. (2001). Effects of protein level and supplementation of Enzyme preparations in diets of growing rabbits. Proc. 8th Conf. Anim. Nutr., 23-26 Oct., Sharm El-Sheikh, Egypt.

SAS (1998). Statistical Analysis System guide: (6th edition) Institute Inc. Cary. Nc. USA.

Singh, P., N.N. Pathak and J.C. Biswas (1997). Performance of broiler rabbit (Soviet Chinchilla * Grey Giant) fed low grain concentration. World Rabbit Sci., 5(3):121-123.

Thomas, J.; M.S. Moersen and F. Robert (1984). Relation of dietary carbohydrate to lipid metabolism and the status of zinc and chromium in rabbits. Anim. J. Vet. Res. 45(6):1238-1241.

Xiccato, G.; A. Trocino; A. Sartori and P.I. Queaque (2002). Effect of dietary starch level and source on performance, caecal fermentation and meat quality in growing rabbits. World Rabbit Sci., 10(4):147157. 


\section{تأثير مستويات مختلفة من نشا و بروتين العليقة على الأداء الإنتاجي للأرانب النامية. \\ علاء الدين عبد السلام حميد، فتحي عبد العظيم محمد، محمد أحمد عفيفي و مراد حامد السنهوري \\ قسم إنتاج الدواجن- كلية الزراعة- جامعة عين شعس- القاهرة- مصر.}

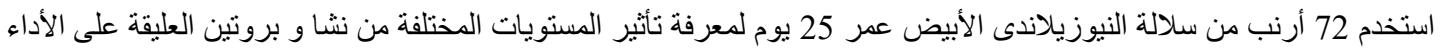

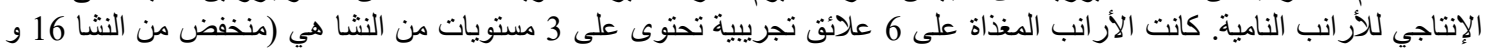

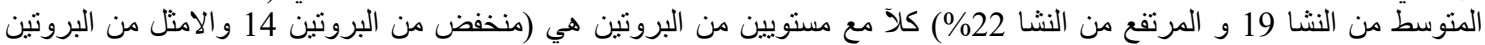
16\% في تصميم عنو ائي متداخل.

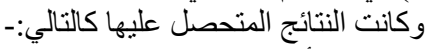
1 ـ ـ كانت أفضل نتيجة منحصل علئها لوزن الجسم الحي لار انب المغذى على العليقة (16\% نشا و14\% بروتين) عند نهاية فترة النمو 81 يوم من العمر. 2 - كان لانخفاض مستوى نثا وبروتين العليقة تأثير ايجابي و معنوي على متوسط الزيادة الوزنية اليومية للجسم في الفترة الكلية للنمو

3 - نأثر معدل استهلاك العليقة بالمستويات المختلفة من النشاو ليس بمستوى البروتين.

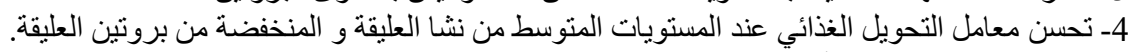

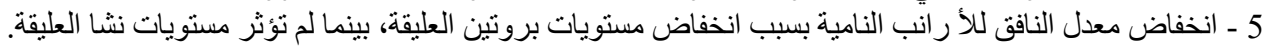

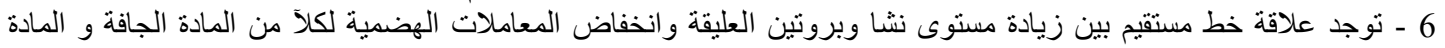
العضوية و البروتين الخام و المستخلص الخالي من النتروجين والنشا والسكر و القيم الغذائية (مجموع المركبات المهضومة و و نسبة البروتين

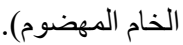
7ـ لم تؤثر المستويات المختلفة من نثا أو بروتين العليقة على المعاملات الهضمية الخاصة بالألياف الخام ومثتقات الألياف ومستخلص الدهن.

8- أثر التداخل بين النثاو البروتين على الأداء الإنتاجي و المعاملات الهضمية السابقة تأثير ا معنويا.

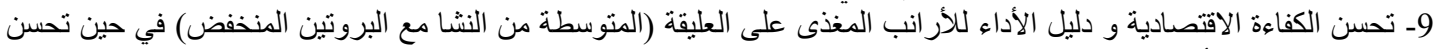

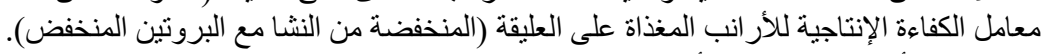
في الأر انب النامية وجد أن هناك ارتباط قوى بين نشاو بروتين العاليقة و التي تنعكس على الأداء الإنتاجي و المعاملات الهضمية و 
Table (2). Effect of different levels of starch and protein on growth performance of growing rabbits.

\begin{tabular}{|c|c|c|c|c|c|c|c|c|c|c|c|c|c|}
\hline \multicolumn{2}{|l|}{ Items } & \multicolumn{4}{|c|}{ 25-53 days } & \multicolumn{4}{|c|}{ 53-81 days } & \multicolumn{4}{|c|}{ 25-81 days } \\
\hline Protein & Starch & LBW & DWG & FI & FCR & LBW & DWG & FI & FCR & DWG & FI & FCR & MR \\
\hline $\mathrm{L}$ & $\mathrm{L}$ & $1353 \pm 25$ & $30 \pm 0.7$ & $68.2 \pm 0.9$ & $2.29 \pm 0.03$ & $2102 \pm 14$ & $26.7 \pm 0.4$ & $100.4 \pm 1.6$ & $3.76 \pm 0.02$ & $28.3 \pm 0.3$ & $84.3 \pm 0.9$ & $2.98 \pm 0.02$ & 8.33 \\
\hline $\mathrm{L}$ & M & $1318 \pm 13$ & $30 \pm 0.5$ & $67.9 \pm 0.8$ & $2.31 \pm 0.1$ & $2042 \pm 16$ & $19.8 \pm 0.1$ & $90.7 \pm 0.9$ & $4.59 \pm 0.02$ & $24.6 \pm 0.2$ & $79.3 \pm 0.7$ & $3.22 \pm 0.04$ & 25.00 \\
\hline $\mathrm{L}$ & $\mathrm{H}$ & $1300 \pm 18$ & $29 \pm 0.58$ & $63.4 \pm 3.0$ & $2.21 \pm 0.1$ & $2072 \pm 23$ & $25.9 \pm 0.7$ & $85.86 \pm 0.9$ & $3.33 \pm 0.05$ & $27.3 \pm 0.9$ & $74.6 \pm 0.8$ & $2.74 \pm 0.03$ & 16.67 \\
\hline $\mathrm{O}$ & $\mathrm{L}$ & $1328 \pm 9.2$ & $28+0.21$ & $60.0 \pm 2.2$ & $2.18 \pm 0.1$ & $1881 \pm 8.1$ & $26.7 \pm 0.8$ & $109.6 \pm 2.7$ & $4.11 \pm .02$ & $27.1 \pm 0.5$ & $84.8 \pm 1.4$ & $3.13 \pm 0.02$ & 16.67 \\
\hline $\mathrm{O}$ & $\mathrm{M}$ & $1281 \pm 13$ & $28 \pm 1.2$ & $62.9 \pm 2.2$ & $2.26 \pm 0.02$ & $2028 . \pm 31$ & $27.6 \pm 1.1$ & $118 \pm 5.43$ & $4.28 \pm 0.12$ & $27.7 \pm 0.3$ & $90.4 \pm 2.3$ & $3.27 \pm 0.06$ & 8.33 \\
\hline $\mathrm{O}$ & $\mathrm{H}$ & $1163 \pm 13$ & $23 \pm 0.50$ & $67.9 \pm 1.1$ & $2.96 \pm 0.1$ & $1846 \pm 19$ & $24.4 \pm 0.6$ & $113.7 \pm 3.6$ & $4.66 \pm 0.04$ & $23.7 \pm 0.5$ & $90.8 \pm 2.3$ & $3.84 \pm 0.05$ & 25.00 \\
\hline \multicolumn{14}{|c|}{ Effect of protein } \\
\hline Low & & $1323.8^{\mathrm{a}}$ & $28.76^{\mathrm{a}}$ & 64.82 & $2.25^{\mathrm{b}}$ & $2072.0^{\mathrm{a}}$ & $26.72^{\mathrm{a}}$ & 101.41 & $3.79^{b}$ & $27.74^{\mathrm{a}}$ & 83.11 & $3.00^{\mathrm{b}}$ & 11.11 \\
\hline High & & $1257.3^{\mathrm{b}}$ & $26.69^{b}$ & 65.24 & $2.48^{\mathrm{a}}$ & $1918.4^{\mathrm{b}}$ & $23.62^{\mathrm{b}}$ & 104.69 & $4.45^{\mathrm{a}}$ & $25.14^{\mathrm{b}}$ & 84.96 & $3.39^{\mathrm{a}}$ & 22.22 \\
\hline \multicolumn{14}{|c|}{ Effect of starch } \\
\hline $\mathrm{L}$ & & $1340.4^{\mathrm{a}}$ & $29.62^{\mathrm{a}}$ & $68.02^{\mathrm{a}}$ & $2.30^{\mathrm{b}}$ & $1991.4^{b}$ & $23.25^{\mathrm{b}}$ & $95.56^{\mathrm{b}}$ & $4.18^{b}$ & $26.43^{\mathrm{b}}$ & $81.79^{b}$ & $3.10^{\mathrm{b}}$ & 16.67 \\
\hline M & & $1299.6^{\mathrm{b}}$ & $28.14^{\mathrm{b}}$ & $61.68^{\mathrm{b}}$ & $2.19^{c}$ & $2035.2^{\mathrm{a}}$ & $26.27^{\mathrm{a}}$ & $97.74^{\mathrm{b}}$ & $3.72^{c}$ & $27.21^{\mathrm{a}}$ & $79.71^{\mathrm{c}}$ & $2.93^{c}$ & 16.67 \\
\hline $\mathrm{H}$ & & $1231.1^{\mathrm{c}}$ & $25.38^{\mathrm{c}}$ & $65.39^{\mathrm{b}}$ & $2.61^{\mathrm{a}}$ & $1958.8^{\mathrm{b}}$ & $25.99^{\mathrm{a}}$ & $115.84^{\mathrm{a}}$ & $4.47^{\mathrm{a}}$ & $25.69^{c}$ & $90.61^{\mathrm{a}}$ & $3.55^{\mathrm{a}}$ & 16.67 \\
\hline \multicolumn{14}{|c|}{ Significance } \\
\hline $\mathrm{P}$ & & $* *$ & $* *$ & $* *$ & $* *$ & $*$ & $* *$ & $* *$ & $* *$ & $* *$ & $* *$ & $* *$ & \\
\hline S & & $* *$ & $* *$ & NS & $* *$ & $* *$ & $* *$ & NS & $* *$ & $* *$ & NS & $* *$ & \\
\hline $\mathrm{P} * \mathrm{~S}$ & & $* *$ & $* *$ & $* *$ & $* *$ & $* *$ & $* *$ & $* *$ & $* *$ & $* *$ & $* *$ & $* *$ & \\
\hline
\end{tabular}

Aa,b,c Means within the same effect and column with no common superscript differ significantly $(p \leq 0.05)$. NS: Non-significant $* *:(P \leq 0.01)$.

$L B W=$ Live body weight, $D W G=$ Daily weight gain, $F I=$ feed intake, $F C R=F e e d$ conversion ratio and $M R=$ Mortality rate.

levels of starch $\{16(L S), 19(M S)$ and $22 \%(H S)\}$ and 2 levels of protein $\{14(L P)$ and $16 \%(O P)\}$ 
Table (3).Effect of different levels of starch and protein on nutrients digestibility and nutritive values.

\begin{tabular}{|c|c|c|c|c|c|c|c|c|c|c|c|c|c|}
\hline \multirow{2}{*}{ Protein } & \multirow[b]{2}{*}{ Starch } & \multicolumn{6}{|c|}{ Digestibility Coefficients } & \multicolumn{6}{|c|}{ Nutritive values } \\
\hline & & $\mathrm{DM}$ & $\mathrm{OM}$ & $\mathrm{CP}$ & $\mathrm{CF}$ & $\mathrm{EE}$ & NFE & NDF & $\mathrm{ADF}$ & Starch & Sugar & TDN & DCP \\
\hline Low & $\mathrm{L}$ & $70.2 \pm 0.35$ & $72.1 \pm 0.23$ & $70.7 \pm 1.02$ & $20.0 \pm 0.98$ & $79.3 \pm 2.15$ & $78.7 \pm 1.95$ & $41.5 \pm 0.97$ & $21.8 \pm 1.3$ & $83.8 \pm 0.96$ & $93.2+0.5$ & $70.3 \pm 1.0$ & $12.2 \pm 0.2$ \\
\hline Low & M & $68.5 \pm 0.11$ & $69.5 \pm 0.16$ & $66.5 \pm 1.03$ & $20.3 \pm 1.02$ & $77.5 \pm 3.16$ & $74.0 \pm 1.85$ & $40.5 \pm 1.20$ & $22.3 \pm 1.4$ & $80.2 \pm 0.47$ & $88.8 \pm 0.2$ & $65.7 \pm 0.6$ & $11.0 \pm 0.1$ \\
\hline Low & $\mathrm{H}$ & $69.4 \pm 0.18$ & $71.4 \pm 0.33$ & $68.5 \pm 0.95$ & $20.3 \pm 1.04$ & $78.4 \pm 1.15$ & $75.0 \pm 1.80$ & $42.3 \pm 1.12$ & $22.1 \pm 1.1$ & $81.0 \pm 0.55$ & $90.0 \pm 1.0$ & $67.3 \pm 0.6$ & $11.2 \pm 0.2$ \\
\hline Optimum & $\mathrm{L}$ & $66.5 \pm 0.37$ & $68.0 \pm 0.13$ & $62.2 \pm 0.34$ & $19.4 \pm 0.95$ & $75.4 \pm 1.99$ & $70.0 \pm 1.00$ & $42.5 \pm 1.16$ & $23.3 \pm 1.0$ & $75.2 \pm 0.85$ & $85.2 \pm 0.6$ & $62.7 \pm 1.0$ & $10.3 \pm 0.2$ \\
\hline Optimum & M & $66.9 \pm 0.13$ & $68.5 \pm 0.25$ & $64.5 \pm 0.35$ & $19.6 \pm 0.86$ & $76.2 \pm 2.03$ & $72.1 \pm 0.98$ & $42.0 \pm 0.95$ & $22.1 \pm 1.2$ & $77.4 \pm 1.00$ & $86.9 \pm 0.2$ & $64.2 \pm 0.6$ & $11.0 \pm 0.2$ \\
\hline Optimum & $\mathrm{H}$ & $62.9 \pm 0.33$ & $64.2 \pm 0.16$ & $60.3 \pm 0.46$ & $19.3 \pm 0.77$ & $74.7 \pm 2.00$ & $66.2 \pm 1.35$ & $42.0 \pm 0.93$ & $22.3 \pm 1.1$ & $71.0 \pm 2.25$ & $81.1 \pm 1.1$ & $60.2 \pm 0.1$ & $10.0 \pm 0.1$ \\
\hline \multicolumn{14}{|c|}{ Main effects: } \\
\hline \multicolumn{14}{|c|}{ Effect of protein } \\
\hline Low & & $69.36^{\mathrm{a}}$ & $70.98^{\mathrm{a}}$ & $68.56^{\mathrm{a}}$ & 20.19 & 78.35 & $75.91^{\mathrm{a}}$ & 41.41 & 22.05 & $81.66^{\mathrm{a}}$ & $90.65^{\mathrm{a}}$ & $67.77^{\mathrm{a}}$ & $11.47^{\mathrm{a}}$ \\
\hline High & & $65.41^{\mathrm{b}}$ & $66.85^{\mathrm{b}}$ & $62.33^{\mathrm{b}}$ & 19.38 & 75.51 & $69.41^{\mathrm{b}}$ & 42.16 & 22.59 & $74.51^{\mathrm{b}}$ & $84.40^{\mathrm{b}}$ & $62.34^{\mathrm{b}}$ & $10.42^{\mathrm{b}}$ \\
\hline \multicolumn{14}{|c|}{ Effect of starch } \\
\hline $\mathrm{L}$ & & $68.37^{\mathrm{a}}$ & $70.04^{\mathrm{a}}$ & $66.45^{\mathrm{a}}$ & 19.68 & 77.34 & $74.34^{\mathrm{a}}$ & 41.96 & 22.55 & $79.48^{\mathrm{a}}$ & $89.17^{\mathrm{a}}$ & $66.5^{\mathrm{a}}$ & $11.28^{\mathrm{a}}$ \\
\hline M & & $67.68^{\mathrm{a}}$ & $68.95^{\mathrm{ab}}$ & $65.5^{\mathrm{ab}}$ & 19.94 & 76.84 & $73.04^{\mathrm{ab}}$ & 41.23 & 22.19 & $78.76^{\mathrm{ab}}$ & $87.86^{\mathrm{ab}}$ & $64.92^{\mathrm{ab}}$ & $10.99^{\mathrm{ab}}$ \\
\hline $\mathrm{H}$ & & $66.11^{\mathrm{b}}$ & $67.75^{\mathrm{b}}$ & $64.38^{\mathrm{b}}$ & 19.75 & 76.61 & $70.60^{\mathrm{b}}$ & 42.17 & 22.21 & $76.03^{\mathrm{b}}$ & $85.57^{\mathrm{b}}$ & $63.75^{\mathrm{b}}$ & $10.57^{b}$ \\
\hline \multicolumn{14}{|c|}{ Significance } \\
\hline $\mathrm{P}$ & & $* *$ & $* *$ & $* *$ & NS & NS & $* *$ & NS & NS & $* *$ & $* *$ & $* *$ & $* *$ \\
\hline$S$ & & $*$ & $* *$ & $* *$ & NS & $*$ & $*$ & NS & NS & $* *$ & $* *$ & $* *$ & $* *$ \\
\hline $\mathrm{P} * \mathrm{~S}$ & & $* *$ & $* *$ & $* *$ & NS & NS & $* *$ & NS & NS & $* *$ & $* *$ & $* *$ & $* *$ \\
\hline
\end{tabular}


Egyptian J. Nutrition and Feeds (2015)

Table (4). Effect of different levels of starch and protein on carcass and digestive tract measurements.

\begin{tabular}{|c|c|c|c|c|c|c|c|c|c|c|c|c|c|}
\hline Protein & Starch & $\begin{array}{l}\text { Dressing } \\
\%\end{array}$ & $\begin{array}{l}\text { Carcass } \\
\%\end{array}$ & $\begin{array}{l}\text { Liver } \\
\%\end{array}$ & FSW\% & ESW\% & FSIW\% & ESIW\% & FLIW\% & EFLW\% & FCW\% & ECW\% & $\begin{array}{l}\text { Caecum } \\
\text { Length }\end{array}$ \\
\hline Low & $\mathrm{L}$ & $58.7 \pm 1.6$ & $50.0 \pm 1.6$ & $3.0 \pm 0.1$ & $5.6 \pm 0.6$ & $1.0 \pm 0.1$ & $3.6 \pm 0.1$ & $3.0 \pm 0.1$ & $2.4 \pm 0.1$ & $1.2 \pm 0.1$ & $5.6 \pm 0.1$ & $2.2 \pm 0.2$ & $1.6+0.1$ \\
\hline Low & M & $57.9 \pm 1.2$ & $48.2 \pm 1.2$ & $3.1+0.1$ & $4.9 \pm 0.3$ & $1.1 \pm 0.1$ & $4.0+0.1$ & $3.3 \pm 0.1$ & $2.0 \pm 0.1$ & $1.7 \pm 0.1$ & $6.3 \pm 0.2$ & $1.7 \pm 0.1$ & $1.8+0.1$ \\
\hline Low & $\mathrm{H}$ & $58.6 \pm 1.1$ & $48.1 \pm 1.1$ & $4.2 \pm 0.4$ & $5.8 \pm 0.7$ & $1.2 \pm 0.2$ & $4.3 \pm 0.1$ & $3.5 \pm 0.1$ & $2.5 \pm 0.2$ & $1.5 \pm 0.2$ & $5.7 \pm 0.4$ & $1.7 \pm 0.3$ & $1.6 \pm 0.1$ \\
\hline Optimum & $\mathrm{L}$ & $58.9 \pm 0.3$ & $49.2 \pm 0.4$ & $2.9 \pm 0.2$ & $3.6 \pm 0.2$ & $1.0 \pm 0.1$ & $3.8 \pm 0.3$ & $3.2 \pm 0.1$ & $2 . \overline{1 \pm 0} 0.2$ & $2.0 \pm 0.2$ & $5.6 \pm 0.3$ & $1.8 \pm 0.2$ & $1 . \overline{7} 0.2$ \\
\hline Optimum & M & $59.9 \pm 2.5$ & $45.0 \pm 2.3$ & $3.5 \pm 0.3$ & $3.4 \pm 0.5$ & $1.2 \pm 0.2$ & $3.8 \pm 0.2$ & $3 . \overline{3 \pm 0} 0.1$ & $2.7 \pm 0.4$ & $1.7 \pm 0.1$ & $5.8 \pm 0.2$ & $1.6 \pm 0.1$ & $2.1 \pm 0.2$ \\
\hline Optimum & $\mathrm{H}$ & $59.9 \pm 1.1$ & $48.3 \pm 0.4$ & $4.6 \pm 0.3$ & $5.3 \pm 0.3$ & $1.1 \pm 0.1$ & $4.7 \pm 0.1$ & $3.4 \pm 0.1$ & $3.1 \pm 0.1$ & $2.2 \pm 0.1$ & $6.1 \pm 0.4$ & $1.9 \pm 0.2$ & $2.3 \pm 0.1$ \\
\hline \multicolumn{14}{|c|}{ Main effects:- } \\
\hline Low & & 58.41 & 48.78 & 3.45 & $4.10^{\mathrm{b}}$ & 1.11 & 3.95 & 3.27 & $2.3^{b}$ & $1.44^{\mathrm{b}}$ & 5.88 & 1.87 & $1.642^{\mathrm{b}}$ \\
\hline High & & 59.59 & 49.14 & 3.70 & $5.41^{\mathrm{a}}$ & 1.11 & 4.13 & 3.29 & $2.6^{0 \mathrm{a}}$ & $2.01^{\mathrm{a}}$ & 5.83 & 1.76 & $2.039^{\mathrm{a}}$ \\
\hline \multicolumn{14}{|c|}{ Effect of starch } \\
\hline $\mathrm{L}$ & & 58.80 & 49.58 & $2.98^{\mathrm{c}}$ & $4.55^{\mathrm{b}}$ & 1.03 & $3.67^{\mathrm{c}}$ & $3.11^{\mathrm{b}}$ & $2.24^{\mathrm{b}}$ & $1.58^{\mathrm{b}}$ & 5.64 & 1.99 & $1.653^{\mathrm{b}}$ \\
\hline M & & 58.92 & 49.10 & $3.32^{\mathrm{b}}$ & $4.16^{b}$ & 1.15 & $3.94^{b}$ & $3.27^{\mathrm{ab}}$ & $2.35^{\mathrm{ab}}$ & $1.74^{\mathrm{ab}}$ & 6.02 & 1.67 & $1.953^{\mathrm{a}}$ \\
\hline $\mathrm{H}$ & & 59.29 & 48.19 & $4.43^{\mathrm{a}}$ & $5.55^{\mathrm{a}}$ & 1.15 & $4.51^{\mathrm{a}}$ & $3.47^{\mathrm{a}}$ & $2.77^{\mathrm{a}}$ & $1.86^{\mathrm{a}}$ & 5.90 & 1.77 & $\begin{array}{c}1.916^{\mathrm{a}} \\
\text { Significance }\end{array}$ \\
\hline $\mathrm{P}$ & & NS & NS & $* *$ & $*$ & NS & $* *$ & $*$ & $*$ & $*$ & NS & NS & $* *$ \\
\hline$S$ & & NS & NS & NS & $*$ & NS & NS & NS & $* *$ & $* *$ & NS & NS & $* *$ \\
\hline $\mathrm{P} * \mathrm{~S}$ & & NS & NS & $*$ & NS & NS & NS & NS & $* *$ & $*$ & NS & NS & $*$ \\
\hline
\end{tabular}

$\overline{a, b, c}$ Means within the same effect and column with no common superscript differ significantly $(p<0.05)$. FSW, ISW= full and empty stomach weight; FSIW, ESIW= full and empty small intestine weight $; F L I W, E F L W=$ full and empty large intestine weight $; F C W, E C W=$ full and empty caecum weight. 
Table (5). Effect of different levels of starch and protein on blood constituents.

\begin{tabular}{|c|c|c|c|c|c|c|c|c|c|}
\hline Protein & Starch & $\begin{array}{l}\text { Total protein } \\
(\mathrm{g} / \mathrm{dl})\end{array}$ & $\begin{array}{l}\text { Albumin } \\
(\mathrm{g} / \mathrm{dl})\end{array}$ & Globulin (g/dl) & A/G ratio & Glucose $(\mathrm{g} / \mathrm{dl})$ & $\begin{array}{c}\text { Triglycerides } \\
(\mathrm{g} / \mathrm{dl})\end{array}$ & $\begin{array}{l}\text { GOT } \\
(\mathrm{u} / \mathrm{l})\end{array}$ & $\begin{array}{l}\text { GPT } \\
(\mathrm{u} / \mathrm{l})\end{array}$ \\
\hline Low & $\mathrm{L}$ & $6.96 \pm 0.18$ & $3.66 \pm 0.11$ & $3.31 \pm 0.09$ & $1.11 \pm 0.03$ & $133.93 \pm 0.84$ & $164.5 \pm 0.61$ & $29.36 \pm 0.45$ & $9.29 \pm 0.36$ \\
\hline Low & $\mathrm{M}$ & $6.85 \pm 0.29$ & $3.39 \pm 0.21$ & $3.46 \pm 0.16$ & $0.99 \pm 0.07$ & $118.13 \pm 0.66$ & $140.5 \pm 0.65$ & $30.46 \pm 0.48$ & $9.65 \pm 0.23$ \\
\hline Low & $\mathrm{H}$ & $6.90 \pm 0.42$ & $3.52 \pm 0.20$ & $3.38 \pm 0.22$ & $1.05+0.01$ & $129.84+1.21$ & $101.5 \pm 0.64$ & $30.27 \pm 0.79$ & $9.55 \pm 0.21$ \\
\hline Optimum & $\mathrm{L}$ & $6.99 \pm 0.21$ & $3.60+0.10$ & $3.39 \pm 0.17$ & $1.07 \pm 0.05$ & $96.530 \pm 1.73$ & $159.5 \pm 0.63$ & $29.40 \pm 0.32$ & $9.39+0.23$ \\
\hline Optimum & M & $6.98 \pm 0.16$ & $3.57 \pm 0.01$ & $3.41 \pm 0.15$ & $1.05 \pm 0.05$ & $107.35+0.41$ & $130.5 \pm 0.65$ & $30.32 \pm 0.50$ & $9.69 \pm 0.27$ \\
\hline Optimum & $\mathrm{H}$ & $7.18 \pm 0.30$ & $3.57 \pm 0.17$ & $3.61 \pm 0.13$ & $0.99 \pm 0.02$ & $91.99 \pm 1.39$ & $94.5 \pm 0.62$ & $30.43 \pm 0.36$ & $9.61 \pm 0.30$ \\
\hline \multicolumn{9}{|c|}{ Main effects: } & Effect of Protein \\
\hline Low & & 6.90 & 3.52 & 3.47 & 1.05 & $127.3^{\mathrm{A}}$ & $135.5^{\mathrm{A}}$ & 30.03 & 9.50 \\
\hline High & & 7.05 & 3.58 & 3.38 & 1.03 & $98.62^{\mathrm{B}}$ & $128.17^{\mathrm{B}}$ & 30.05 & 9.56 \\
\hline \multicolumn{10}{|c|}{ Effect of Starch } \\
\hline $\mathrm{L}$ & & 6.97 & 3.63 & 3.35 & 1.09 & $115.23^{\mathrm{a}}$ & $162.0^{\mathrm{a}}$ & 29.38 & 9.34 \\
\hline M & & 6.91 & 3.48 & 3.43 & 1.02 & $112.74^{\mathrm{ab}}$ & $135.5^{\mathrm{ab}}$ & 30.39 & 9.67 \\
\hline $\mathrm{H}$ & & 7.04 & 3.55 & 3.49 & 1.02 & $110.92^{\mathrm{b}}$ & $98.0^{\mathrm{b}}$ & 30.35 & 9.58 \\
\hline \multicolumn{10}{|c|}{ Significance } \\
\hline $\mathrm{P}$ & & NS & NS & NS & NS & $* *$ & $* *$ & NS & NS \\
\hline$S$ & & NS & NS & NS & NS & $* *$ & $* *$ & NS & NS \\
\hline $\mathrm{P} * \mathrm{~S}$ & & NS & NS & NS & NS & $* *$ & $* *$ & NS & NS \\
\hline
\end{tabular}

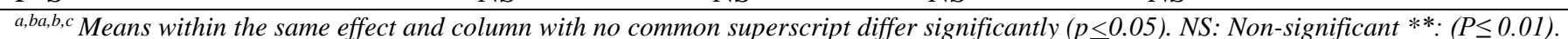


Table (6).Total protein in digestion content of stomach, ileum \& caecum \& total volatile fatty acids and pH in the digestive system of growing rabbits.

\begin{tabular}{|c|c|c|c|c|c|c|c|c|c|}
\hline \multicolumn{10}{|c|}{ Total protein Total VFA pH } \\
\hline Protein & Starch & Stomach & Ileum & Caecum & Caecum & Blood & Stomach & Ileum & Cecum \\
\hline Low & $\mathrm{L}$ & $10.75 \pm 0.2$ & $43.5 \pm 3.22$ & $50.5 \pm 1.44$ & $3.81 \pm 0.03$ & $3.01 \pm 0.02$ & $1.76 \pm 0.04$ & $6.02 \pm 0.01$ & $5.02 \pm 0.04$ \\
\hline Low & M & $7.25 \pm \overline{0} .47$ & $35.5 \overline{0} \pm 0.3$ & $36.5 \pm 1.19$ & $3.52+0.04$ & $2.71+0.11$ & $1.85 \pm 0.03$ & $6.44+0.02$ & $5.23+0.02$ \\
\hline Low & $\mathrm{H}$ & $8.5 \pm 0.13$ & $36.15+0.4$ & $41.35+2.6$ & $3.73+0.01$ & $2.93+0.03$ & $1.80 \pm 0.03$ & $6.17 \pm 0.01$ & $5.05 \pm 0.03$ \\
\hline Optimum & $\mathrm{L}$ & $4.2 \overline{7} \pm 0.60$ & $29.25 \pm 1.2$ & $30.00 \pm 0.7$ & $3.29 \pm 0.02$ & $2.49 \pm 0.04$ & $2.10 \pm 0.04$ & $6.63 \pm 0.02$ & $5.44 \pm 0.07$ \\
\hline Optimum & M & $5.75 \pm 0.47$ & $32.50 \pm 0.9$ & $31.2 \pm 1.20$ & $3.37 \pm 0.03$ & $2.57 \pm 0.01$ & $2.02 \pm 0.03$ & $6.50 \pm 0.01$ & $5.31 \pm 0.02$ \\
\hline Optimum & $\mathrm{H}$ & $3.85 \pm 0.59$ & $24.75 \pm 0.9$ & $20.01 \pm 1.1$ & $2.67 \pm 0.23$ & $1.87 \pm 0.15$ & $2.26 \pm 0.04$ & $6.73 \pm 0.03$ & $5.51 \pm 0.05$ \\
\hline \multicolumn{10}{|c|}{ Main effects: } \\
\hline Low & & $8.8^{\mathrm{a}}$ & $39.05^{\mathrm{a}}$ & $42.78^{\mathrm{a}}$ & $3.69^{\mathrm{a}}$ & $2.88^{\mathrm{a}}$ & $1.80^{\mathrm{b}}$ & $6.21^{\mathrm{b}}$ & $5.10^{\mathrm{b}}$ \\
\hline High & & $4.62^{\mathrm{b}}$ & $28.83^{\mathrm{b}}$ & $27.07^{\mathrm{b}}$ & $3.11^{\mathrm{b}}$ & $2.31^{\mathrm{b}}$ & $2.13^{\mathrm{a}}$ & $6.62^{\mathrm{a}}$ & $5.42^{\mathrm{a}}$ \\
\hline \multicolumn{10}{|c|}{ Effect of starch } \\
\hline $\mathrm{L}$ & & $7.51^{\mathrm{a}}$ & $36.38^{\mathrm{a}}$ & $40.25^{\mathrm{a}}$ & $3.55^{\mathrm{a}}$ & $2.75^{\mathrm{a}}$ & $1.93^{\mathrm{b}}$ & $6.325^{\mathrm{b}}$ & $5.23^{\mathrm{b}}$ \\
\hline M & & $6.5^{\mathrm{ab}}$ & $34.00^{\mathrm{ab}}$ & $33.85^{\mathrm{ab}}$ & $3.45^{\mathrm{ab}}$ & $2.64^{\mathrm{ab}}$ & $1.94^{\mathrm{b}}$ & $6.470^{\mathrm{a}}$ & $5.27^{\mathrm{a}}$ \\
\hline $\mathrm{H}$ & & $6.18^{\mathrm{b}}$ & $31.45^{\mathrm{b}}$ & $30.68^{b}$ & $3.20^{\mathrm{b}}$ & $2.40^{\mathrm{b}}$ & $2.03^{\mathrm{a}}$ & $6.450^{\mathrm{ab}}$ & $5.28^{\mathrm{a}}$ \\
\hline \multicolumn{10}{|c|}{ Significance } \\
\hline $\mathrm{P}$ & & $* *$ & $* *$ & $* *$ & $* *$ & $* *$ & $*$ & $*$ & $*$ \\
\hline$S$ & & $* *$ & $* *$ & $* *$ & $* *$ & $* *$ & $* *$ & $* *$ & $* *$ \\
\hline $\mathrm{P} * \mathrm{~S}$ & & $* *$ & $* *$ & $* *$ & $* *$ & $* *$ & $* *$ & $*$ & $*$ \\
\hline
\end{tabular}


Table (7). Digestive enzyme activities of growing rabbits fed different levels of starch and protein

\begin{tabular}{|c|c|c|c|c|c|c|c|c|c|c|c|c|c|}
\hline \multirow[b]{2}{*}{ Protein } & \multirow[b]{2}{*}{ Starch } & \multicolumn{4}{|c|}{ Stomach } & \multicolumn{4}{|c|}{ Ileum } & \multicolumn{4}{|c|}{ Caecum } \\
\hline & & Amylase & Cellulase & $\mathrm{CMC}$ & Protease & Amylase & Cellulase & $\mathrm{CMC}$ & Protease & Amylase & Cellulase & $\mathrm{CMC}$ & Protease \\
\hline \multirow{3}{*}{ Low } & \multirow{3}{*}{$\mathrm{L}$} & $0.53 \pm 0.2$ & $0.58 \pm 0.2$ & $0.006 \pm 0$ & $3.91 \pm 0.0$ & $0.71 \pm 0.0$ & $2.51 \pm 0.2$ & $0.08 \pm 0.0$ & $2.91 \pm 0.1$ & $2.01 \pm 0.0$ & $2.39 \pm 0.2$ & $0.07 \pm 0.0$ & $2.13 \pm 0.0$ \\
\hline & & & & & 9 & & $\overline{5}$ & $\overline{1}$ & 9 & $\overline{3}$ & $\overline{0}$ & $\overline{1}$ & $8^{-}$ \\
\hline & & $0.4 \pm 0.05$ & $0.38+0.1$ & $0.005 \pm 0$ & $3.01 \pm 0.0$ & $0.45 \pm 0.0$ & $2.27 \pm 0.2$ & $0.07 \pm 0.0$ & $2.01 \pm 0.0$ & $1.41 \pm 0.0$ & $1.86+0.2$ & $0.05 \pm 0.0$ & $1.76 \pm 0.0$ \\
\hline \multirow[t]{2}{*}{ Low } & \multirow[t]{2}{*}{ M } & & & & $\overline{7}$ & & $\overline{3}$ & $\overline{1}$ & 9 & 2 & 9 & 1 & 9 \\
\hline & & $0.44 \underline{ \pm 0.1}$ & $0.46 \pm 0.1$ & $0.005 \pm 0$ & $3.32 \pm 0.0$ & $0.61 \pm 0.0$ & $2.34 \pm 0.2$ & $0.08 \pm 0.0$ & $2.35 \pm 0.1$ & $1.91 \pm 0.0$ & $2.14 \pm 0.2$ & $0.07 \pm 0.0$ & $1.97 \pm 0.0$ \\
\hline \multirow[t]{2}{*}{ Low } & \multirow[t]{2}{*}{$\mathrm{H}$} & & & & $8^{-}$ & & $\overline{5}$ & $\overline{1}$ & 3 & $\overline{4}$ & $\overline{1}$ & $\overline{1}$ & $\overline{3}$ \\
\hline & & $0.22 \pm 0.0$ & $0.23 \pm 0.1$ & $0.005 \pm 0$ & $2.35 \pm 0.0$ & $0.35 \pm 0.0$ & $1.95 \pm 0.2$ & $0.07 \pm 0.0$ & $1.40 \pm 0.0$ & $1.01 \pm 0.0$ & $1.40 \pm 0.1$ & $0.05 \pm 0.0$ & $1.36 \pm 0.1$ \\
\hline \multirow[t]{2}{*}{ Optimum } & \multirow[t]{2}{*}{$\mathrm{L}$} & 2 & &. & $\overline{4}$ & & $\overline{6}$ & 1 & 7 & 4 & 8 & 1 & 9 \\
\hline & & $0.31+0.0$ & $0.37 \pm 0.1$ & $0.005 \pm 0$ & $2.85 \pm 0.0$ & $0.40 \pm 0.0$ & $2.05 \pm 0.2$ & $0.07 \pm 0.0$ & $1.95 \pm 0.0$ & $1.36 \pm 0.0$ & $1.55+0.1$ & $0.05 \pm 0.0$ & $1.65 \pm 0.0$ \\
\hline \multirow[t]{2}{*}{ Optimum } & \multirow[t]{2}{*}{$\mathrm{M}$} & $\overline{5}$ & & & $\overline{6}$ & 1 & 8 & 1 & 8 & 9 & 9 & 1 & $\overline{5}$ \\
\hline & & $0.17 \pm 0.0$ & $0.20 \pm 0.1$ & $0.004 \pm 0$ & $2.00 \pm 0.0$ & $0.21 \pm 0.0$ & $1.82 \pm 0.2$ & $0.06 \pm 0.0$ & $1.19 \pm 0.0$ & $0.81 \pm 0.0$ & $1.23 \pm 0.2$ & $0.024 \pm 0$ & $1.00 \pm 0.1$ \\
\hline Optimum & $\mathrm{H}$ & 3 & &. & 3 & 0 & 9 & 1 & 4 & 1 & 6 & 0 & 2 \\
\hline \multicolumn{13}{|c|}{ Main effects: } & Effect of protein \\
\hline \multicolumn{2}{|c|}{ Low } & $0.44^{\mathrm{A}}$ & 0.473 & 0.0055 & $3.41^{\mathrm{A}}$ & $0.592^{\mathrm{A}}$ & 2.373 & 0.075 & $2.423^{\mathrm{A}}$ & $1.78^{\mathrm{A}}$ & 2.130 & 0.066 & $1.953^{\mathrm{A}}$ \\
\hline \multicolumn{2}{|l|}{ High } & $0.23^{\mathrm{B}}$ & 0.267 & 0.0046 & $2.40^{\mathrm{B}}$ & $0.321^{\mathrm{B}}$ & 1.940 & 0.066 & $1.513^{\mathrm{B}}$ & $1.06^{\mathrm{B}}$ & 1.393 & 0.038 & $1.337^{\mathrm{B}}$ \\
\hline \multicolumn{14}{|c|}{ Effect of starch } \\
\hline \multicolumn{2}{|c|}{$\mathrm{L}$} & $0.38^{\mathrm{a}}$ & 0.405 & 0.0049 & $3.13^{\mathrm{a}}$ & $0.531^{\mathrm{a}}$ & 2.23 & 0.075 & $2.16^{\mathrm{a}}$ & $1.51^{\mathrm{a}}$ & 1.893 & 0.060 & $1.745^{\mathrm{a}}$ \\
\hline \multicolumn{2}{|l|}{ M } & $0.34^{\mathrm{ab}}$ & 0.374 & 0.0041 & $2.93^{\mathrm{ab}}$ & $0.427^{\mathrm{ab}}$ & 2.16 & 0.068 & $1.98^{\mathrm{ab}}$ & $1.39^{\mathrm{ab}}$ & 1.710 & 0.048 & $1.705^{\mathrm{ab}}$ \\
\hline \multicolumn{2}{|l|}{$\mathrm{H}$} & $0.31^{\mathrm{b}}$ & 0.332 & 0.0041 & $2.66^{\mathrm{b}}$ & $0.411^{\mathrm{b}}$ & 2.08 & 0.070 & $1.77^{\mathrm{b}}$ & $1.36^{\mathrm{b}}$ & 1.690 & 0.048 & $1.485^{\mathrm{b}}$ \\
\hline \multicolumn{14}{|c|}{ Significance } \\
\hline \multicolumn{2}{|l|}{$\mathrm{P}$} & $* *$ & NS & NS & $* *$ & $* *$ & NS & NS & $* *$ & $*$ & NS & NS & $* *$ \\
\hline \multicolumn{2}{|l|}{ S } & $* *$ & NS & NS & $* *$ & $* *$ & NS & NS & $* *$ & $* *$ & NS & NS & $* *$ \\
\hline \multicolumn{2}{|l|}{$\mathrm{P} * \mathrm{~S}$} & $* *$ & NS & NS & $* *$ & $* *$ & NS & NS & $* *$ & $* *$ & NS & NS & $* *$ \\
\hline
\end{tabular}


Egyptian J. Nutrition and Feeds (2015)

Table (8). Economic and Productive Efficiency of growing rabbits fed different levels of starch and protein diets.

\begin{tabular}{|c|c|c|c|c|c|c|c|c|c|c|}
\hline Protein & Starch & $\begin{array}{c}\text { Average of feed } \\
\text { consumed } \\
\text { (Kg/rabbit) }\end{array}$ & $\begin{array}{l}\text { Price / Kg } \\
\text { feed (LE) }\end{array}$ & $\begin{array}{l}\text { Total feed } \\
\text { cost (LE) }\end{array}$ & $\begin{array}{l}\text { Average weight } \\
\text { gain (Kg / rabbit) }\end{array}$ & $\begin{array}{l}\text { Total } \\
\text { return } \\
(\mathrm{LE})^{*}\end{array}$ & $\begin{array}{l}\text { Net } \\
\text { return } \\
(\mathrm{LE})\end{array}$ & $\begin{array}{c}\text { Economic } \\
\text { Efficiency }(\%)\end{array}$ & $\begin{array}{l}\text { Performance } \\
\text { Index (PI) }\end{array}$ & $\begin{array}{l}\text { Production } \\
\text { Efficiency Factor } \\
(\mathrm{PEF})\end{array}$ \\
\hline Low & $\mathrm{L}$ & 4.72 & 0.79 & 3.75 & 1.58 & 14.24 & 10.50 & 280.03 & 70.53 & 79.92 \\
\hline Low & $\mathrm{M}$ & 4.18 & 0.80 & 3.34 & 1.53 & 13.75 & 10.41 & 311.80 & 74.54 & 76.68 \\
\hline Low & $\mathrm{H}$ & 5.06 & 0.80 & 4.07 & 1.55 & 13.96 & 9.89 & 167.26 & 63.36 & 71.70 \\
\hline Optimum & $\mathrm{L}$ & 4.44 & 0.81 & 3.60 & 1.38 & 12.40 & 8.80 & 244.44 & 58.42 & 54.09 \\
\hline Optimum & $\mathrm{M}$ & 4.75 & 0.84 & 4.00 & 1.25 & 13.67 & 9.67 & 241.60 & 64.79 & 66.66 \\
\hline Optimum & $\mathrm{H}$ & 5.08 & 0.88 & 4.47 & 1.33 & 11.94 & 7.47 & 267.26 & 48.07 & 44.51 \\
\hline \multicolumn{11}{|c|}{ Main effects: } \\
\hline Low & & 4.65 & 0.80 & 3.72 & 1.22 & 13.98 & 10.26 & 278.25 & 69.48 & 76.07 \\
\hline High & & 4.76 & 0.84 & 4.02 & 1.14 & 12.78 & 8.65 & 217.77 & 57.09 & 55.09 \\
\hline \multicolumn{11}{|c|}{ Effect of starch } \\
\hline $\mathrm{L}$ & & 4.58 & 0.80 & 3.67 & 1.48 & 13.32 & 9.25 & 262.24 & 64.48 & 66.96 \\
\hline M & & 4.47 & 0.82 & 3.67 & 1.53 & 13.71 & 10.04 & 276.70 & 69.67 & 71.67 \\
\hline $\mathrm{H}$ & & 5.07 & 0.84 & 4.27 & 1.44 & 12.95 & 8.68 & 205.10 & 55.72 & 58.11 \\
\hline
\end{tabular}

